[6] Mamone, G., Picariello, G., Caira, S., Addeo, F., Ferranti, P. (2009). Analysis of food proteins and peptides by mass spectrometry-based techniques. Journal of Chromatography A, 1216 (43), 7130-7142. doi: https://doi.org/10.1016/j.chroma.2009.07.052

[7] Boichak, Ya., Koberniuk, V., Petryk, L. (2018). Novi vydy i formy biodobavok v tekhnolohiyi molochnykh produktiv LPN. Dni studentskoi nauky u LNUVM ta BT imeni S.Z Hzhytskoho: Materialy studentskoi konferentsii. Lviv, 79-80.

[8] Turchyn, I., Zalensky, M., Voychishin, A. (2018). Development of technology of cereal past with combined composition. Scientific Messenger of LNU of Veterinary Medicine and Biotechnologies, 20 (85), 24-28. doi: https://doi.org/10.15421/nvlvet8505

[9] Nagovska, V., Hachak, Y., Gutyj, B., Bilyk, O., Slyvka, N. (2018). Influence of wheat bran on quality indicators of a sour milk beverage. Eastern-European Journal of Enterprise Technologies, 4 (11 (94)), 28-35. doi: https://doi.org/10.15587/1729-4061.2018.140093

[10] Simakhina, H. O. (2011). Biolohichna tsinnist ta funktsionalna diya komponentiv krioporoshkiv tsukrovykh buriakiv. Tsukor Ukrainy, 6-7.

\title{
PROBATION OF THE APPARATUS FOR LOW-TEMPERATE PROCESSING OF MEAT CULINARY PRODUCTS BY IR-RADIATION
}

\author{
Andrii Zahorulko \\ Department of Processes, Devices and Automation of Food Production \\ Kharkiv State University of Food Technology and Trade \\ 333 Klochkivska str., Kharkiv, Ukraine, 61051 \\ zagorulkoAN@hduht.edu.ua \\ Aleksey Zagorulko \\ Department of Processes, Devices and Automation of Food Production \\ Kharkiv State University of Food Technology and Trade \\ 333 Klochkivska str., Kharkiv, Ukraine, 61051 \\ zagorulko@hduht.edu.ua \\ Maryna Yancheva \\ Department of Meat Technology \\ Kharkiv State University of Food Technology and Trade \\ 333 Klochkivska str., Kharkiv, Ukraine, 61051 \\ ya.marina11@gmail.com \\ Maksym Serik \\ Department of Chemistry, Microbiology and Food Hygiene \\ Kharkiv State University of Food Technology and Trade \\ Director of the Educational and Scientific Institute of Food Technology and Business \\ of Kharkiv State University of Food Technology and Trade \\ 333 Klochkivska str., Kharkiv, Ukraine, 61051 \\ serik_m@hduht.edu.ua

\section{Sergei Sabadash} \\ Department of engineering technology of food production \\ Sumy national agrarian University \\ 160 G. Kondratiev str., Sumy, Ukraine, 40021 \\ s.v.sabadash@ukr.net
}




\author{
Marina Savchenko-Pererva \\ Department of engineering technology of food production \\ Sumy National Agrarian University \\ 160 G. Kondratiev str., Sumy, Ukraine, 40021 \\ marina.saw4encko2011@gmail.com
}

\begin{abstract}
The improvement of existent technological processes of making meat culinary products and development of the correspondent principally new resource-effective equipment is an urgent task. There was probated the developed apparatus of the low-temperature processing of meat culinary products by IR-radiation with the further qualitative assessment of ready culinary products for solving it.

The results of the conducted studies provide making high-quality, juicy meat products without a crust that generally provides spreading the assortment of products under conditions of their low-temperature processing in a price category, attractive for a consumer.

A flexible film resistive electric heater of the radiating type (FFREhRT) was used as a heating element for providing the even low-temperature processing of meat products at the expanse of taking the working geometry of a chamber of the apparatus by it. For providing the autonomy of the work of air-ejecting ventilators, there was offered to use Peltier elements that allow to transform secondary heat of FFREhRT in the low-voltage feeding tension and to provide cooling of the external surface of the apparatus synchronously. The apparatus is mobile that provides its displacement directly in places of realization. At the studies, there was established the culinary readiness degree of meat products of the spheric form with diameter $0,1 \pm 0,01 \mathrm{~m}$ by reaching temperature $53 \ldots 85^{\circ} \mathrm{C}$ in the product center.

The evenness of the heat flow distribution within the working chamber was proved by the data, obtained from thermocouples, placed on the metal spheric model of a meat product sample in real time by 7 thermocouples.

As a result of analyzing the geometric model of placing Peltier elements, it has been established, that for providing the low-voltage tension of ventilators at level 3,55 V, 10 successively connected elements are necessary.

The offered innovative construction-technological solutions allow to make high-quality, juicy meat products without a crust that generally provides spreading the assortment of products under conditions of their low-temperature processing.

Keywords: culinary meat products, low-temperature processing, IR-radiation, original taste. Maksym Serik, Sergei Sabadash, Marina Savchenko-Pererva
\end{abstract}

\title{
1. Introduction
}

Meat culinary products traditionally occupy one of main steps of the ration of the most population of European countries, so, they need not only widening the assortment, but guaranteeing making high-quality products [1]. The everyday growth conditions the necessity of widening their assortment by improving technological processes for decreasing mass losses of products at production stages and developing the new equipment. At that the unessential part of existing apparatuses is characterized by autonomy in the aspect of using secondary heat for technological needs. It causes the necessity in improving technologically processes of making meat culinary products and development of the principally new mobile, portable and resource-effective equipment in whole [2].

One of ways of decreasing mass losses of meat raw materials is their low-temperature processing, at which a culinary product is considered as ready at reaching temperature $53 \ldots 85{ }^{\circ} \mathrm{C}$ in its center. It must be noted, that, high-temperature inertial heating elements are used for most existent equipments, designed for the low-temperature processing of high culinary products that complicate their technical maintenance, increase metal-consumption, so, their cost [3]. It conditions the development of apparatuses with rational technical-economic parameters, simplified exploitation parameters and less price, designed for being used in hotel-restaurant business, home life and places of meat products realization.

Under today market conditions a consumer needs high-quality culinary meat products directly at places of their consumption under conditions of providing high-quality properties and original taste [4]. Thus, the necessity of creating the new technological equipment, characterized by mobility, portability and decreased resource consumption, is an urgent task. 
For today just low-temperature processing is spreading more and more in many countries of the world at making high-quality meat culinary products with original taste properties [5]. One of classic methods of the low-temperature processing of meat products is cooling [6], but it is of high energy-consumption, technical complicacy of maintenance and essential capital costs at realization, and above all doesn't provide products, ready for consumption [7, 8]. One of known methods of the modern low-temperature processing of meat products is Sous vide, based on preliminary preparation of vacuumed food in a water bath [9], but this technology is not completely studied in the aspect of the influence of different technological factors on it, namely: physical-chemical changes of processed raw materials [10]. The use of a water bath technically complicates the management of temperature-regime parameters in it, so, conditions methods of the further technological improvement.

It must be taken into account that most ways of the low-temperature processing of meat culinary products are based on using imperfect thermal processing methods $[11,12]$. It results in not only constructive-technological complications, but also in the increase of a non-substantiated price for the equipment for its realization, and one of obtained products in whole. The attention must be also paid to resource effectiveness, namely a possibility of using secondary heat [13], because any secondary energy, gained at realization of the technological process, can be directed for example on the autonomous work of certain construction elements.

There is also a necessity in preparing high-quality meat products without a crust and with original taste properties [14]. This all conditions the topicality of these studies for food industry and for a consumer.

The aim of the work is to conduct the probation studies of the apparatus, developed in the learning center "New biotechnologies and equipment for making food products with high healthy properties" (Kharkiv, Ukraine) for the low temperature processing of high-quality juicy meat products without a crust that generally provides spreading the assortment of products under conditions of their low-temperature processing in a price category, attractive for a consumer.

\section{Materials and Methods}

The probation of studies of the apparatus, developed for the low temperature processing of meat culinary products by IR-radiation was realized in the learning center "New biotechnologies and equipment for making food products with high healthy properties" at the Kharkiv state university of food technologies and trade.

For attaining the set aim of creation of the innovative equipment, there was offered to use modern heating and transforming elements. A flexible film resistive electric heater of the radiating type (FFREhRT) was used as a heating element in the apparatus $[15,16]$ for providing the even low-temperature processing of meat products at the expanse of taking the working geometry of a chamber of the apparatus by it. For providing the autonomy, there was offered to use Peltier elements that allow to transform secondary heat of FFREhRT in the low-voltage feeding tension and to provide cooling of the external surface of the apparatus synchronously. Just mobility provides the function of moving the apparatus easily directly to realization places, and portability is in the use of the constructive-technological solution. At the studies, there was established the culinary readiness degree of meat products by reaching certain temperatures in the product center.

Diverse meat raw materials (pork, chicken, beef and mutton) as fillet or steaks of different forms of soft and hard sorts, further formed in products of the spheric form by a tissue netted sleeve, were used in the studies. The general outlook of formed products is presented on Fig. 1.

For giving meat products a pleasant outlook and good smell before thermal processing, it is necessary to cover them by hand in diverse organic spices of the vegetable origin; for example, in dry mixtures of pink, basil, red and black pepper, rosemary depending on a desirable taste.

The studies were conducted on the experimental apparatus for the low-temperature processing of meat-products by IR-radiation in the complete set with a measuring block, which scheme is presented on Fig. 2. 


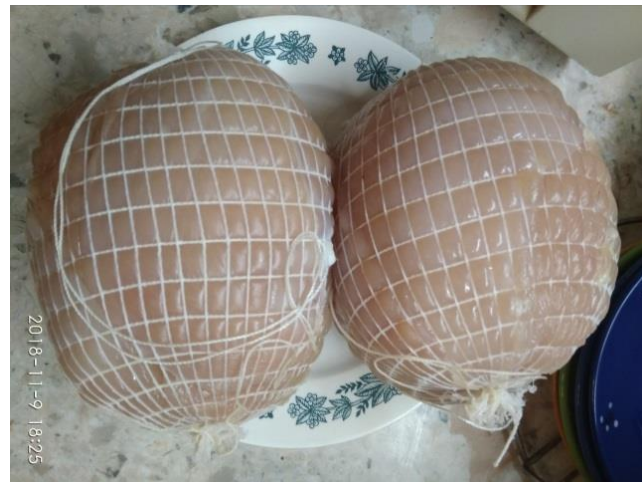

Fig. 1. Formed meat product (chicken fillet) in a netted sleeve before thermal processing

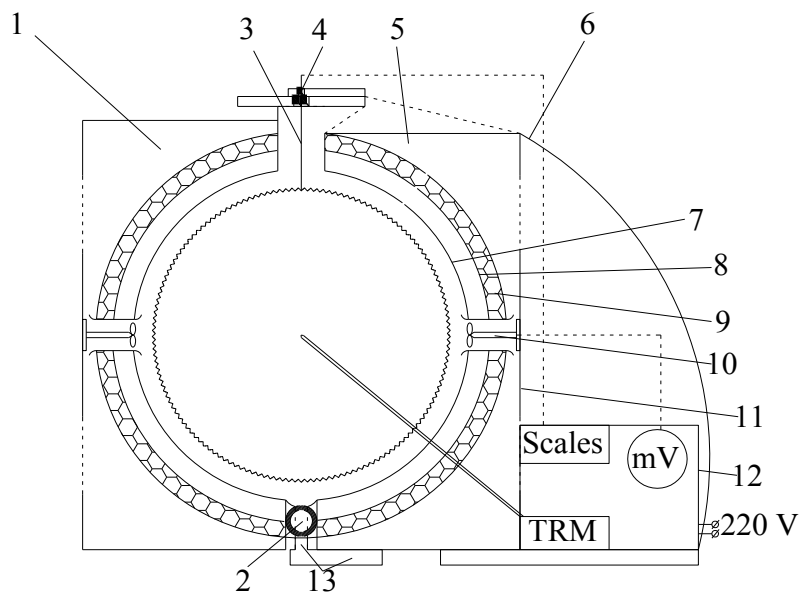

Fig. 2. Scheme of the experimental apparatus for the low-temperature processing of meat products by IR-radiation in the complete set with the measuring block

The work order of the experimental apparatus is that the vertical non-thermally isolated half (drop 1), combined with moving joint 2 opens. After that the preliminarily prepared meat product is placed on hook 3 in the apparatus on vertical semi-spheric half 5, fixed with balance 6 . The meat product, fixed on bar 3, is connected to tensometric transmitter 4 for controlling weight changes at the thermal processing of the product. Transmitter 4 in its turn is connected to management block 12 .

For studying a temperature change of the experimental meat sample, a prickly thermocouple, connected to the measuring thermoregulator (TRM) of the Kharkiv firm "OVEN" (Ukraine) [17] that provides switching FFREnRT 7 off at reaching the set temperature, namely $60{ }^{\circ} \mathrm{C}$ within the product that corresponds to its readiness, was inset in the meat sample center. After these actions, heating halves $(1,2)$ are connected and feeding tension $220 \mathrm{~V}$ is supplied to management block 12 .

At warming heating halves $(1,2)$ heat, absorbed by black absorbing screen 8 , is created on FFREhRT external surface 7. The external surface of 8 contains Peltier elements 9 for transforming heat, gotten by the conductive method from absorbing screen 8 , in low-voltage feeding tension, which values are reflected on management block 12 , by a microvoltmeter. The obtained tension within $\sim 3 \ldots 4 \mathrm{~V}$ is used for the autonomous work of air-ejecting ventilators 10 , inset in transparent orifices and destined for removing wet air from the working space of the apparatus in non-thermally isolated halves 1 and 2, with further removal in the external environment through technical orifices 11 .

Meat juice, created at the low-temperature processing of meat culinary products, is taken through the technical space, combining with accumulating chamber 12, in mobile joint 2 .

FFREhRT was offered $[15,16]$ for providing the even low-temperature processing of meat products. It is able to provide taking the working geometry of a chamber of the apparatus and is 
characterized by the low inertia, even distribution of a thermal flow along the whole surface of a product, reaching the working temperature up to $90{ }^{\circ} \mathrm{C}$ during $5 \mathrm{~min}$ that provides the low-temperature processing.

The autonomy of the work of the air-ejecting ventilators is provided by using Peltier elements, namely by Seebeck effect, based on the appearing thermoelectric motor force in the closed electric chain with successively combined heterogenic conductors, and contacts between them are at different temperatures.

\section{Experimental procedures}

For probating the experimental apparatus for the low-temperature processing of meat products by IR-radiation in the complete set with the measuring lock, there were studied:

- the heating process at achieving the necessary temperature in the product center;

- the distribution evenness of a thermal heat from FFREhRT at absence of an experimental sample in the working chamber;

- the geometric location of Peltier elements on the external surface of the absorbing screen for getting the low-voltage feeding tension;

- the organoleptic assessment of obtained ready culinary products under conditions of their comparison with a control sample of cold baked pork, purchased in the trade net "Denver", "Schiriy kum" trademark, produced by SSU 4668:2006.

3. 1. Studies of heating processes in the apparatus for the low-temperature processing of meat products by IR-radiation

The low-temperature thermal processing in the experimental apparatus was studied at the expanse of placing the experimental meat sample (soft pork) of the spheric form with diameter $0,1 \pm 0,01 \mathrm{~m}$ on the fixing bar and introduction of the pricked thermocouple, combined to TRM that provided switching FFREhRT off at reaching the set temperature in the product center as $60{ }^{\circ} \mathrm{C}$ (culinary readiness). It must be noted, that this temperature is different for another meat raw material, so, it has been established during the study that a temperature in a product center for soft and hard pork is within $53{ }^{\circ} \mathrm{C}-80{ }^{\circ} \mathrm{C}$. For poultry meat it is from $55^{\circ} \mathrm{C}$ to $80{ }^{\circ} \mathrm{C}$, hard and soft beef $55{ }^{\circ} \mathrm{C}-83{ }^{\circ} \mathrm{C}$. So, the thermal processing temperature depends on a type of meat raw materials. At that it must be noted, that FFREhRT reaches the working temperature in the apparatus at level $90{ }^{\circ} \mathrm{C}$ in $5 \mathrm{~min}$.

3. 2. Studies of the distribution evenness of a thermal heat from FFREhRT at absence of an experimental sample in the working chamber

For providing the distribution evenness of a thermal flow from EEREhRT in the working space of the apparatus, a metallic spheric model of the meat product sample with thermocouples, connected to TRM was developed and placed in the working space of the experimental apparatus. It provided the analysis of the temperature field under real time conditions using a computer addition, allowing to connect TRM to a portable PC and to observe the thermal processing in real time [17].

3. 3. Studies of the probable geometric location of Peltier elements on the external surface of the absorbing screen for getting the low-voltage feeding tension

The geometric location of Peltier elements on the external surface of the absorbing screen for getting the low-voltage feeding tension was determined experimentally at the expanse of presenting the semi-spheric surface in the flat unfolded plane that the zoning of a geometric net for placing elements was conventionally realized on. The thermal surface of Peltier elements for providing better heat conductivity from the absorbing screen was fixed on it by the thermoconducting paste.

\section{4. Study of the organoleptic assessment of the obtained ready culinary products}

The study of the organoleptic assessment of the experimentally obtained ready culinary product was realized by the expert commission of the Kharkiv state university of food and trade 
(Kharkiv, Ukraine) of 5 members. The assessment was realized by the 5-point scale by the organoleptic parameters, presented in table 1. During the studies the experimental sample was compared with cold baked pork, purchased in the trade net "Denver". The results of the gustatory assessment are presented in Table $\mathbf{1 .}$

\section{Results}

An example of realization of the low-temperature processing of the experimental meat product sample of soft pork in the experimental apparatus is presented on Fig. $\mathbf{4}$ under conditions of placing 4 thermocouples in it.

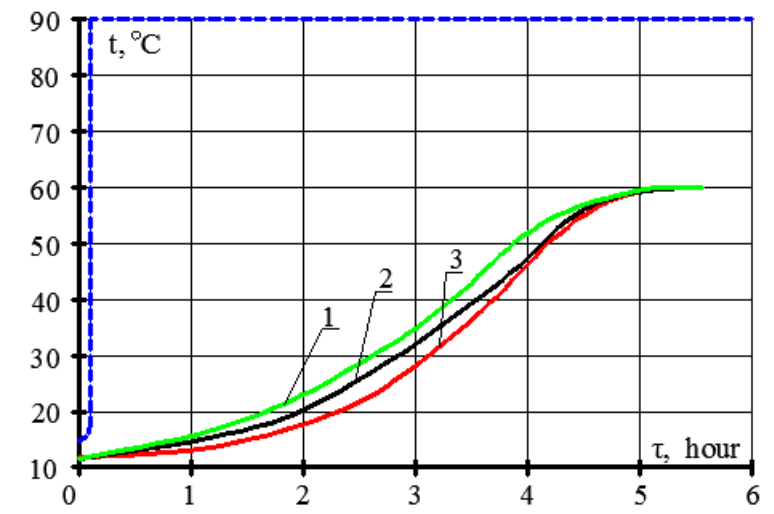

Fig. 4. Process of thermal processing of soft pork at measuring the temperature on the surface, within and in the center of the experimental product: - - duration of reaching the working temperature by FFREhRT $\left(90{ }^{\circ} \mathrm{C}\right) ; 1$ - temperature on the surface; 2 - temperature in the middle layer; 3 - temperature in the center of the experimental sample

As it can be seen of the graph (Fig. 4), the heating evenness is prognosticated, because at the beginning there is observed heating of surface layers of the sample (curve 1). Then heat is gradually transmitted in the middle layer (curve 2) and transferred to the product center (curve 3 ). The difference of temperatures between the curves is not critical, and completely suitable for realizing the thermal process. At that there is provided the main condition of the culinary product's readiness, because the suitable temperature as $60^{\circ} \mathrm{C}$ is reached in the center of the experimental meat sample in 5,4 hours.

The study of the distribution evenness of the thermal flow is proved by the data, obtained from the thermocouples, placed on the metallic spheric model of the meat product sample (Fig. 5).
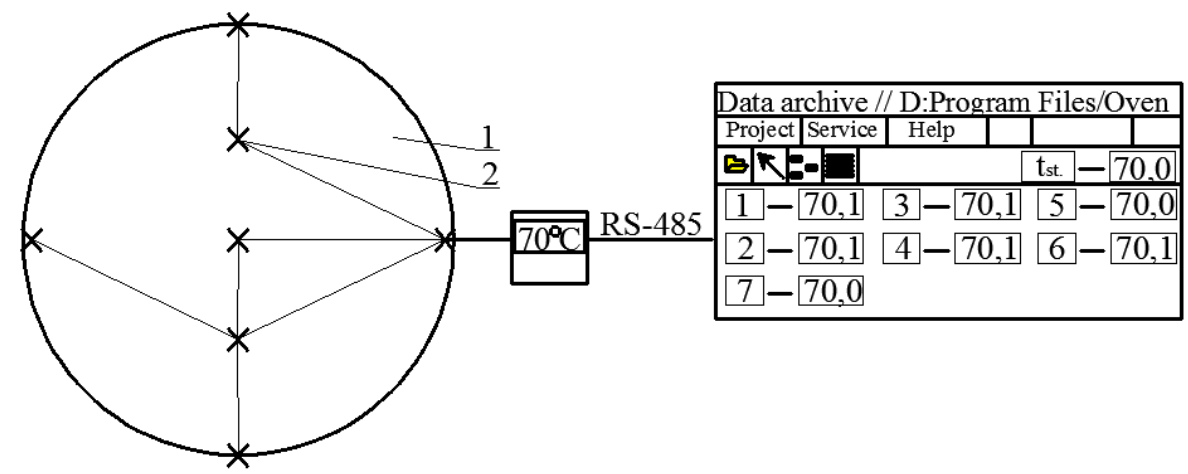

Fig. 5. Scheme of thermocouples location the metallic spheric model of the meat product sample: 1 - model; 2 - thermocouple

The studies were conducted in the diapason of working temperatures from $10{ }^{\circ} \mathrm{C}$ to $90{ }^{\circ} \mathrm{C}$. The evenness of the thermal flow was provided at all temperatures, because it was within a sta- 
tistical mistake of the experiment. As an example of providing the evenness, there was presented the graph at temperature $70{ }^{\circ} \mathrm{C}$. The thermocouples were connected with TRM and reflected by 7 thermocouples in real time using a computer program. The analysis of the obtained data proves the distribution evenness of the thermal flow along the whole taking surface at using FFREhRT as a heater.

For simplifying modeling of Peltier elements location on semi-spheric surfaces of the absorbing screen, there was offered to present them in the spheric space (Fig. 6).

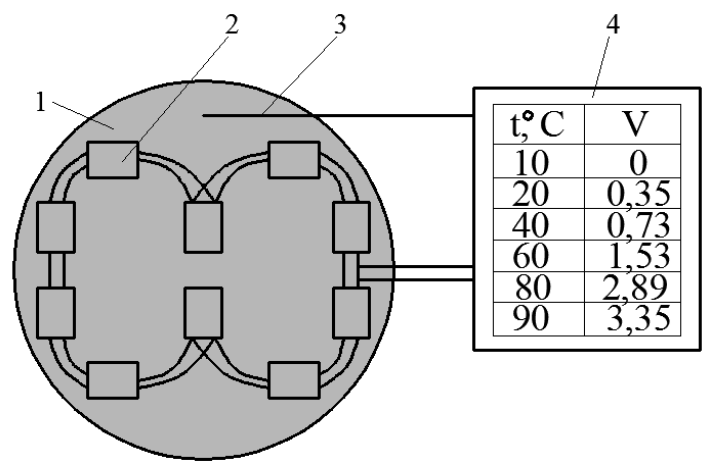

Fig. 6. Geometric model of Peltier elements location on semi-spheric surfaces of the absorbing screen: 1 - surface of the absorbing screen; 2 - Peltier element; 3 - thermocouple with TRM; 4 - measuring block

The main task at modeling was to provide the low-voltage feeding tension by each semisphere, under conditions of connecting Peltier elements successively with geometric sizes of a square of $15 \times 15 \mathrm{~mm}$ and maximal absorbing temperature $150{ }^{\circ} \mathrm{C}$. As a result of analyzing the offered geometric model, it has been established, that for providing the low-voltage feeding tension at level 3,55 V, 10 successively combined elements are necessary, that is proved by the experimental data of the measuring block. So, it can be stated, that the offered geometric model of locating Peltier elements provides the autonomous work of air-ejecting ventilators.

The organoleptic assessment of the experimentally obtained meat product and one, purchased in the trade net "Denver" was conducted, its results are presented in Table $\mathbf{1 .}$

Table 1

Results of the organoleptic assessment of meat products

\begin{tabular}{cccccc}
\hline Meat product sample & Outlook & Consistence & Taste & Natural color & Smell \\
\hline Experimental meat product sample & 5 & 5 & 5 & 5 & 4 \\
One, purchased in the trade net "Denver" & 5 & 4 & 4 & 4 & 4
\end{tabular}

Comparing the results of the visual and gustatory assessment, it is possible to prove the high quality of the developed product, homogenous structure with the pleasant even color, without a crust that in whole provides original taste characteristics and juiciness of products.

\section{Discussion}

Introduction of the developed innovative constructive-technological solution allows to prepare high-quality, juicy meat products without a crust at the expanse of using the modern low-temperature and mobile apparatus that generally provides spreading the assortment of products under conditions of their low-temperature processing.

The presented studies prove the effectiveness of the construction-technological solutions for realizing the low-temperature of meat culinary products by IR-radiation. It became possible at the expanse of using FFREhRT as a heater that, according to the presented research 
results, is able to take any geometric form of the working chamber and to provide the evenness of the thermal flow distribution. Peltier elements allowed to use secondary heat for getting the low-voltage feeding tension due to Seebeck effect for providing the autonomous work of air-ejecting ventilators.

Among research defects there must be noted the need of forming the spheric globule of the product, although it is also an advantage of the technological solution, because just the use of the spheric working chamber and experimental sample provides the maximal evenness of the thermal flow distribution.

The obtained results are topical for being used in hotel-restaurant business, home life and places of realization of culinary meat products with original taste properties. They may be used not only for producing high-quality culinary meat products, but in other directions of meat industry, where the need in the even low-temperature processing of raw materials and transformation of secondary heat for the autonomous work of certain construction elements appears.

\section{Conclusions}

The probation of studies of the apparatus, developed for the low temperature processing of meat culinary products by IR-radiation was realized by the experimental-practical studies. It has been established, that the heating evenness of the experimental sample is prognosticated that is proved by the results, obtained by 3 thermocouples. At that the main condition of the culinary product's readiness is provided, because the suitable temperature as $60^{\circ} \mathrm{C}$ is reached in the center of the experimental sample in 5,4 hours. The evenness of the thermal flow distribution in the working chamber under conditions of using FFREhRT has been proved.

For providing the autonomous work of the air-ejecting ventilators, Peltier elements were fixed in the apparatus. It has been established, according to the offered geometric model of their location, that that for providing the low-voltage feeding tension at level 3,55 V, 10 successively combined elements are necessary.

The gustatory assessment proved the advantage of the developed product, made by the low-temperature method that had a homogenous structure with the pleasant even color, without a crust that in whole provides original taste characteristics, juiciness without forming a crust that in general provides original taste properties.

\section{References}

[1] Pankova, N. V. (Ed.) (2012). Innovacionnye tekhnologii v oblasti pishchevyh produktov i produkcii obshchestvennogo pitaniya funkcional'nogo i specializirovannogo naznacheniya. Sankt-Peterburg: Izd-vo «LEMA», 314.

[2] Prodovol'stvenniy prognoz (2018). Prodovol'stvennaya i sel'skohozyaystvennaya organizaciya Ob'edinennyh Naciy. Available at: http://www.fao.org/3/CA0910RU/ca0910ru.pdf

[3] Mostenska, T. (2009). Stan ta perspektyvy rozvytku rynku prodovolchykh tovariv v Ukraini. Kharchova i pererobna promyslovist, 1 (353), 8-12.

[4] Vlasenko, N. S. (Ed.) (2013). Balansy ta spozhyvannia osnovnykh produktiv kharchuvannia naselenniam Ukrainy. Kyiv: Derzhavna sluzhba statystyky Ukrainy, 56.

[5] Dominguez-Hernandez, E., Salaseviciene, A., Ertbjerg, P. (2018). Low-temperature long-time cooking of meat: Eating quality and underlying mechanisms. Meat Science, 143, 104-113. doi: https:// doi.org/10.1016/j.meatsci.2018.04.032

[6] Savinok, O., Kuzelov, A. (2015). Influence of ways of cooling on functional properties of pork. Scientific Works of University of Food Technologies, LXII, 149-152.

[7] Onyshchenko, V. M., Hrynchenko, N. H., Bolshakova, V. A. (2015). Improvement of frozen poultry storage technology. Eastern-European Journal of Enterprise Technologies, 6 (10 (77)), 37-41. doi: https://doi.org/10.15587/1729-4061.2015.54656

[8] Yancheva, M., Dromenko, O., Potapov, V., Grinchenko, O., Zhelieva, T. (2018). Development of a physical-mathematical model for the process of crystallization of meat systems. Eastern-European Journal of Enterprise Technologies, 1 (11 (91)), 50-55. doi: https://doi.org/10.15587/1729-4061.2018.120793 
[9] Roascio-Albistur, A., Gámbaro, A. (2018). Consumer perception of a non-traditional market on sous-vide dishes. International Journal of Gastronomy and Food Science, 11, 20-24. doi: https:/doi.org/ 10.1016/j.ijgfs.2017.10.002

[10] Jeong, K., O, H., Shin, S. Y., Kim, Y.-S. (2018). Effects of sous-vide method at different temperatures, times and vacuum degrees on the quality, structural, and microbiological properties of pork ham. Meat Science, 143, 1-7. doi: https://doi.org/10.1016/j.meatsci.2018.04.010

[11] Zonin, V. G. (2006). Sovremennoe proizvodstvo kolbasnyh i solenokopchenyh izdeliy. SanktPeterburg: Professiya, 224.

[12] Verboloz, E. I., Romanchikov, S. A. (2017). Features of the low-temperature heat treatment of meat products in a combi steamer with the imposition of ultrasonic vibrations. Proceedings of the Voronezh State University of Engineering Technologies, 79 (3), 35-41. doi: https://doi.org/10.20914/2310-1202-2017-3-35-41

[13] Pech' tomleniya, goryachego i holodnogo kopcheniya, hraneniya. Available at: http:// www.istoma.com

[14] Innovacionnye tekhnologii v proizvodstve kulinarnoy produkcii (2014). Sankt-Peterburg, 80.

[15] Zahorulko, O. Ye., Zahorulko, A. M. (2016). Pat. No. 108041 UA. Hnuchkyi plivkovyi rezystyvnyi elektronahrivach vyprominiuiuchoho typu. No. u201600827; declareted: 02.02.2016; published: 24.06.2016, Bul. No. 12. Available at: http://uapatents.com/5-108041-gnuchkijj-plivkovijj-rezistivnijjelektronagrivach-viprominyuyuchogo-tipu.html

[16] Kiptelaya, L., Zahorulko, A., Zagorulko, A., Liashenko, B. (2017). Improvement of IR emitter to create non-reflector dryer for plant raw materials. Technology Audit and Production Reserves, 2 (3 (34)), 17-22. doi: https://doi.org/10.15587/2312-8372.2017.98068

[17] Kontrol'no-izmeritel'nye pribory i sredstva avtomatizacii OVEN.

\title{
INVESTIGATION OF THE EXPEDIENCE OF MODIFICATION OF THE CARBOHYDRATE COMPOSITION OF RICE FLOUR IN THE TECHNOLOGY OF GLUTEN-FREE BREAD
}

\author{
Iryna Medvid \\ Department of Hotel and Restaurant Business \\ National University of Food Technologies \\ 68 Volodymyrska str., Kyiv, Ukraine, 01601 \\ medvidrina@gmail.com \\ Viktor Dotsenko \\ Department of Hotel and Restaurant Business \\ National University of Food Technologies \\ 68 Volodymyrska str., Kyiv, Ukraine, 01601 \\ dotsvf@gmail.com \\ Olena Shydlovska \\ Department of Hotel and Restaurant Business \\ National University of Food Technologies \\ 68 Volodymyrska str., Kyiv, Ukraine, 01601 \\ elena_shydlovska@ukr.net \\ Tetiana Ishchenko \\ Department of Hotel and Restaurant Business \\ National University of Food Technologies \\ 68 Volodymyrska str., Kyiv, Ukraine, 01601 \\ ichenkotat@gmail.com
}

